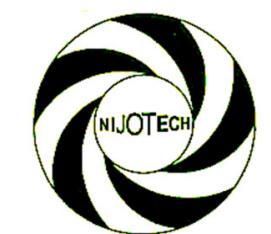

Nigerian Journal of Technology (NIJOTECH)

Vol. 34 No. 2, April 2015, pp. 421 - 428

Copyright@ Faculty of Engineering,

University of Nigeria, Nsukka, ISSN: $1115-8443$

www.nijotech.com

http://dx.doi.org/10.4314/njt.v34i2.29

\title{
REGIONAL SCALE ASSESSMENT OF THE GROSS HYDROKINETIC ENERGY POTENTIALS OF SOME RIVERS IN LOWER NIGER RIVER BASIN, NIGERIA
}

\author{
L. L. Ladokun ${ }^{1, *}$, K. R. Ajao ${ }^{2}$ and B. F. Sule ${ }^{3}$ \\ 1 NATIONAL CENTRE FOR HYDROPOWER RESEARCH AND DEVELOPMENT, UNIVERSITY OF ILORIN, NIGERIA \\ 2 DEPARTMENT OF MECHANICAL ENGINEERING, UNIVERSITY OF ILORIN, NIGERIA \\ 3 DEPARTMENT OF CIVIL ENGINEERING, UNIVERSITY OF ILORIN, NIGERIA \\ E-mail addresses: ${ }^{1}$ niyi_ladokun@yahoo.com, ${ }^{2}$ ajaomech@unilorin.edu.ng, 3 bfsuleiman@gmail.com
}

\begin{abstract}
This study investigates the hydrokinetic energy potential of some selected rivers in the Lower Niger River Basin in North Central Nigeria. The methodology adopted was to obtain the gross naturally occurring theoretical hydrokinetic potential of the rivers through the use of a hydrological model and a spatial tool. MWSWAT, an open source interface to SWAT using the GIS system MapWindow, was employed for simulation to determine the hydrological parameters of the sub-basins and other computations were done using a spreadsheet package to estimate the instantaneous power density along the river reach. Preliminary results show there are naturally occurring potentials of this technology in the Lower Niger River Basin. The estimate of the theoretical resource for the watershed totals 826.7MW (7.247TWh/yr). River Moshi has the highest discharge ( $\left.8315.78 \mathrm{~m}^{3} / \mathrm{secs}\right)$, while Oshin has the lowest (1224.27 $\left.\mathrm{m}^{3} / \mathrm{secs}\right)$. Also, Awun has the highest theoretical hydrokinetic potential of 257.5MW while Oshin has the lowest (20.9MW).
\end{abstract}

Keywords: hydrokinetic energy; resource assessment; hydrological model; spatial tool

\section{INTRODUCTION}

Small scale hydropower schemes are very useful for decentralised power generation and can be very useful in obtaining sustainable, adequate, affordable and available electrical energy. Marine hydrokinetic energy conversion technology, a variant of the small hydropower (SHP) technology, is a class of "zero head" hydropower which are designed to extract the kinetic energy of rivers, streams, tidal currents or other man-made waterways for generation of electricity. Unlike the conventional hydropower scheme which requires hydraulic head and water volume to generate power, hydrokinetic devices utilize the energy in the velocity of the water (in stream) to turn turbines. Their principle of operation is analogous to that of wind turbines, though they capture energy through the process of hydrodynamic, rather than aerodynamic, lift or drag [1]. The available power that can be extracted from a hydrokinetic system is a function of the density of the water, the cross sectional area of the flowing water channel or the turbine and the speed of the water current. The minimum velocity of water current required according to the literature is typically between $1.03 \mathrm{~ms}^{-1}$ and $2.06 \mathrm{~ms}^{-1}$. Optimum currents are in the range of $2.57 m s^{-1}$ to $3.6 m s^{-1}[2]$.

There has been worldwide interest in the technology in recent times particularly in North America, Australia, United Kingdom and some parts of South America [3] and [2]. The Electric Power Research Institute (EPRI) recently completed a mapping and assessment of hydrokinetic resources in rivers of the continental United States and found that these undeveloped resources could provide $3 \%$ of the nation's annual use of electricity [4].Natural Resources Canada [5], embarked on a study to develop a methodology to assess the hydraulic kinetic energy contained in Canadian rivers. This study provided a technique to identify potential sites where hydraulic kinetic turbines could be installed using digital data available at the watershed scale. The study represented a proof-of-concept, and it illustrated the feasibility and potential utility of the method when used with hydrologic software. Miller et al. [6] also 
reported a study to estimate the hydrokinetic resource potential in the United States. The continental US was divided into 16 physiographic/hydrologic regions and hydrometric data from gage stations restricted to river reaches with a certain mean flow rate and flow velocity were obtained and analysed. The total resource potential was estimated by making some important assumptions about turbine configuration and it provided a conservative resource estimate of 12,500 MW. Also, two-dimensional hydrodynamic simulations were performed by Toniolo [7]on a monthly basis along $2.5 \mathrm{~km}$ of the Kvichak River near Igiugig in southwest Alaska, USA, to estimate flow conditions and to assess the hydrokinetic potential of the river reach. Study results indicate that two areas along the river may be suitable for deploying turbines. Nigeria has a vast potential of small scale hydropower which can be exploited and converted to useful energy forms (mechanical/electrical) and hydrokinetic energy conversion scheme provides an innovative approach to tapping the SHP potentials without the cost and the environmental implications of constructing dams. Energy harvested by this method can be used to serve thousands of communities in urban, semi-urban and rural areas as well as areas that are far from the national grid [8].

\section{THE STUDY AREA}

The study area is the Lower Niger River watershed. This is located in the central area of Nigeria between Latitude $9.55^{\circ} \mathrm{N}$, Longitude $3.13^{\circ} \mathrm{E}$ and Latitude $8.52^{\circ} \mathrm{N}$, Longitude $6.52^{\circ} \mathrm{E}$. It encloses Kwara and Kogi States majorly and then some parts of Oyo, Osun and Ekiti states. It is bordered on the north by River Niger and the Upper Niger River Basin, on the west by Benin Republic, on the east by the Benue River Basins and on the south by the Ogun-Oshun River Basins. It has a perimeter of about $998 \mathrm{~km}$ and an estimated area of $48,600 \mathrm{~km}^{2}(4,859,960 \mathrm{ha})$. It forms a sub-basin in the existing Niger River basin situated between Hydrological Zone II and III of Nigeria.

The watershed has River Niger as the main river that passes through it and some major tributaries. Some of these are River Awun with stream length of $115.5 \mathrm{~km}$, River Moshi with stream length 232.22 km, River $O$ Shin with stream length $150 \mathrm{~km}$. Other rivers are $O y i$, Oro, Asa,Oyun etc. The major rivers of the watershed are presented in Figure 1.Stream networks in the watershed, generated by an hydrological model, are shown in Figure 2. Some towns and villages within the watershed area are Ilorin, Bode-Saadu, AjaseIpo, Moshi-gada, Lafiagi, Ejiba and Kpada.

The watershed in focus cuts across three of the six hydrographic regions of the entire Niger River stretch with each being distinguished by their topographic and drainage characteristics. The rock type of the area is basement complex (Precambrian) which lies in the mobile zone between the West Africa and Congo craton. The climate of the study area is that of the tropical savannah which corresponds to Koppen classification $A_{w}[10]$.

Rainfall figures around the watershed, varies from $1,100 \mathrm{~mm}$ in the lowlands to over $2,000 \mathrm{~mm}$ in the highlands. Temperatures are usually above 18 ${ }^{\circ} \mathrm{C}\left(64^{\circ} \mathrm{F}\right)$ throughout the year. They are usually at their lowest in January and December. The harmattan season is between December and March while the rains fall between April and November.

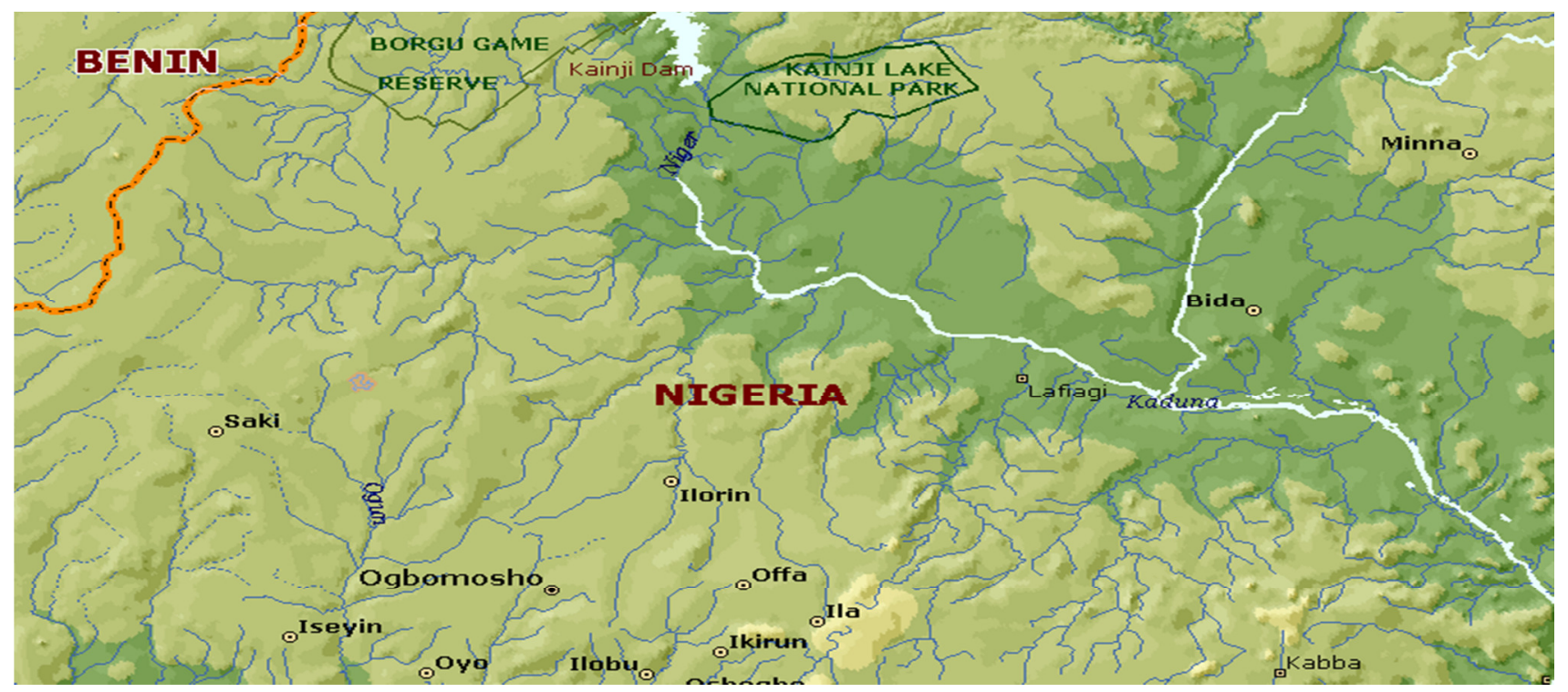


Figure 1: Major Rivers in the Lower Niger River Basin (Source: Microsoft Encarta [9])

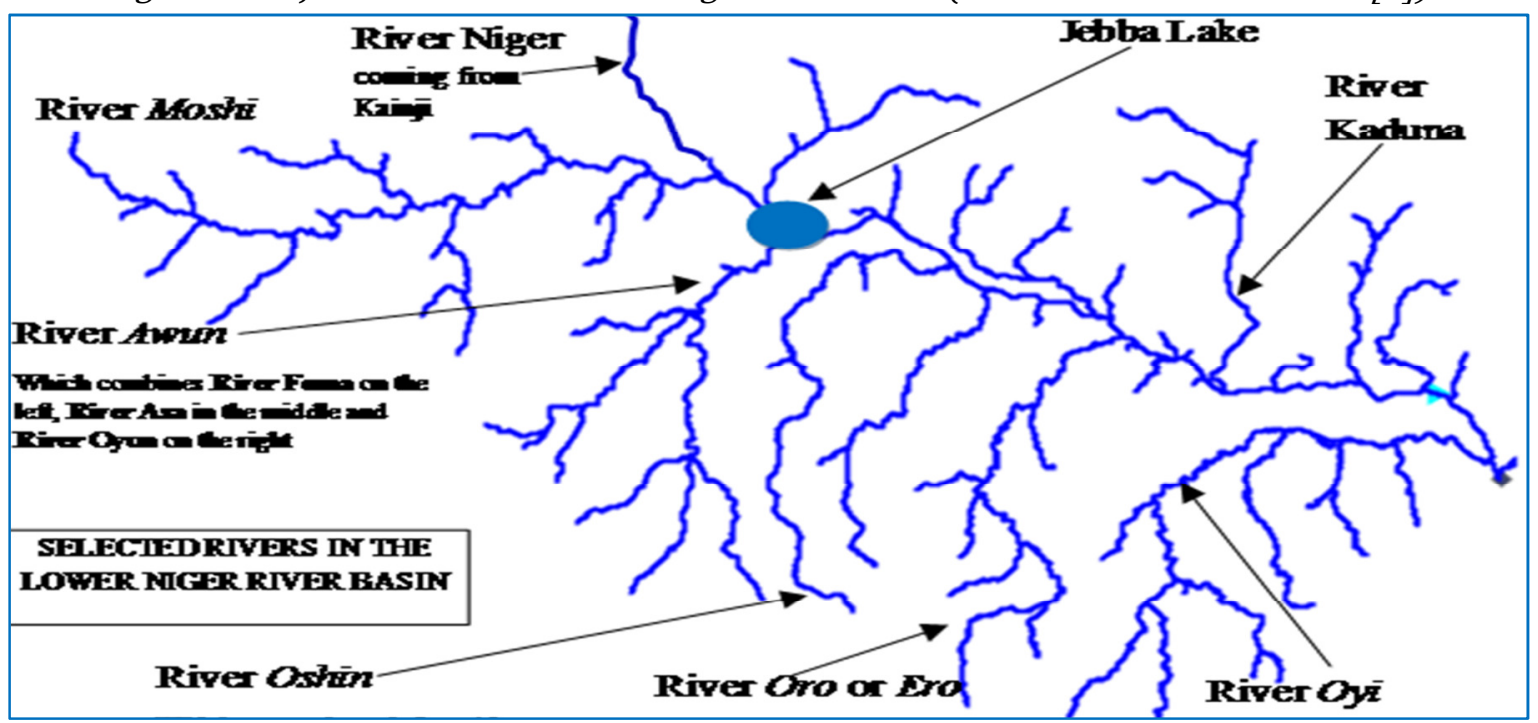

Figure 2: Stream Network of the Rivers in the Lower Niger River Basin

\section{CONCEPTUAL FRAMEWORK FOR THE RESOURCE ASSESSMENT}

The conceptual framework for the regional scale resource assessment was based on Electricity Supply Board International (ESBI) Generic Energy Resource Ranking [11]. This provided a systematic approach of determining and exploiting renewable energy resources of a locality. It divides resource assessment levels to five: theoretical resource; technical resource; practical resource; accessible resource and viable resource. However, for the purpose of this study, the theoretical, naturally occurring resource was investigated on a regional scale to determine the estimated power potential of each site.

\subsection{Obtaining the Theoretical Hydrokinetic Resource}

Theoretical hydrokinetic resource implies the estimated theoretical, segment specific, gross, naturally occurring riverine hydrokinetic resource in the Lower Niger River Basin of central Nigeria. The
MWSWAT (MapWindow Soil Water Assessment Tool), an open source interface to SWAT using the GIS system MapWindow, was used for simulation to determine the hydrological parameters of the subbasins. As a first step to the modeling/simulation process, all required spatial input datasets (Digital Elevation Model (DEM), Land Use Map, Soil map) for MWSWAT were set to the same projection. The Automatic Watershed Delineation (AWD) was launched from the model interface and the base DEM selected. A total of 131 sub-basins were delineated after running AWD as seen in Figure 3.

The creation of Hydraulic Response Units (HRU) followed the sub basin creation. These are further subdivisions that make use of the particular soil and land use /slope range combination. Below is Figure 4; showing the division into HRUs and sub basins and Figure 5 showing stream network of the rivers and the HRUs.

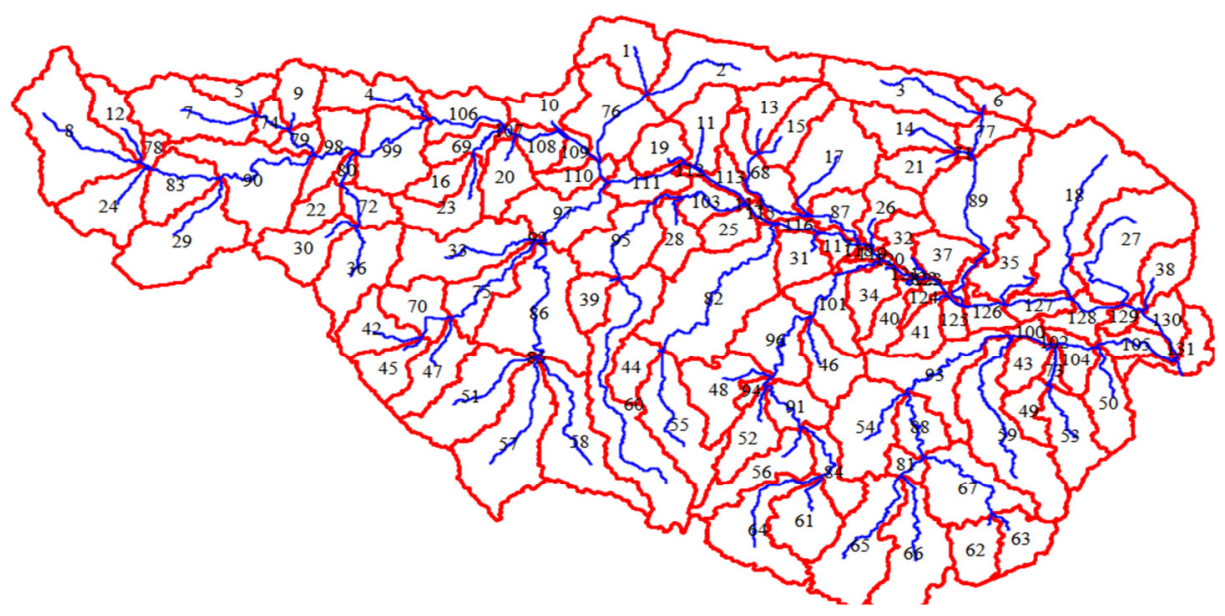


Figure 3: Delineation of Study Area into Sub basins

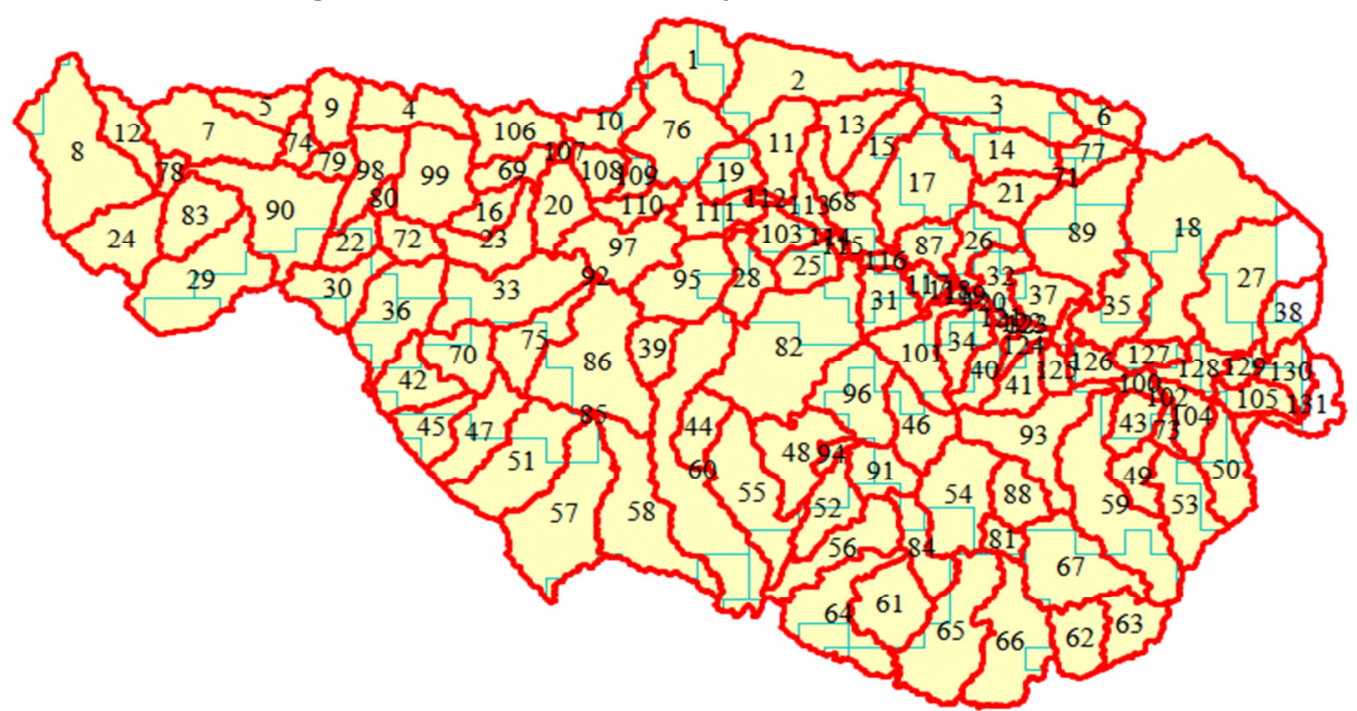

Figure 4: Watershed showing sub basins and HRUs

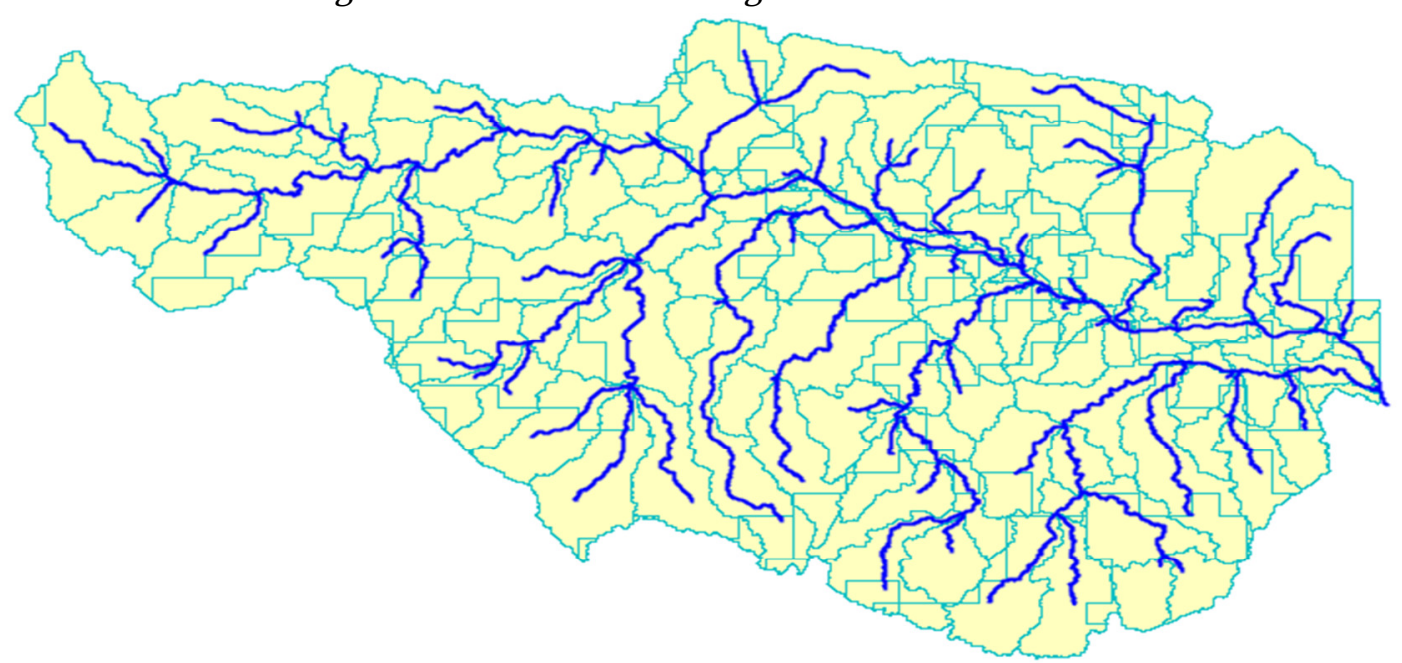

Figure 5: Subdivisions into Hydrological Response Units

Simulation was then initiated using SWAT. Weather values were selected from their sources in the SWAT database. For the initial run of the model, simulation period was set from 01 January 2000 to Dec 312010. All the necessary files needed to run SWAT were written at this level and the appropriate selection of weather sources done before running the SWAT executables.

\subsection{MWSWAT Preliminary Results Generated}

MWSWAT outputs were visualized by colouring the sub basins according to the value of the output generated. Figure 6 shows the result of the maximum discharge entering each sub basin. It can be observed that the highest flow obtained was towards the Niger River. The output in spatial form of the computed mean annual flow entering and leaving each sub basin is presented in Figures 7 and 8 respectively. The total mean annual discharge of the five major rivers across the watershed is presented in Figure 9(a). Figure 9(b) presents the mean annual discharge along each subbasin the rivers navigated.

\section{COMPUTATION OF THE REGIONAL THEORETICAL HYDROKINETIC POWER ESTIMATE}

These preliminary results obtained from this stage were inputted to obtain the theoreticallyavailable instream hydrokinetic power in a given river segment $P_{t h}$, (Watts) according to the equation,

$$
P_{t h}=\gamma Q \Delta H
$$

In (1), $Q$ is the segment specific average water discharge generated by MWSWAT in units of cubic meters per second. Hydraulic head $(\Delta \mathrm{H})$ is calculated from segment length and slope due to the parameters of the software, simplicity of computation and from previous resource assessments [5]. $\gamma$ is the specific weight of water $\left(9800 \mathrm{Nm}^{-3}\right)$. The computations were made using a Microsoft Excel spreadsheet software 
package to estimate the instantaneous power density along the river reach in the whole region. Meteorological data needed for the simulation was obtained from the Lower Niger River Basin Development Authority and the World Meteorological Organisation database. Table 1 presents the hydraulic parameters of the river sites while Figure10 shows the power along the sub basins.
It can be observed that Awun at sub-basin 97 has the highest value for mean hydrokinetic power and holds the highest potential in the watershed. By using Google earth, Aderan community, off Jebba road is located in the sub-basin. Sub-basin 91 in River Ero also holds a very good hydrokinetic potential. Ahun near Oro-Ago is located there.

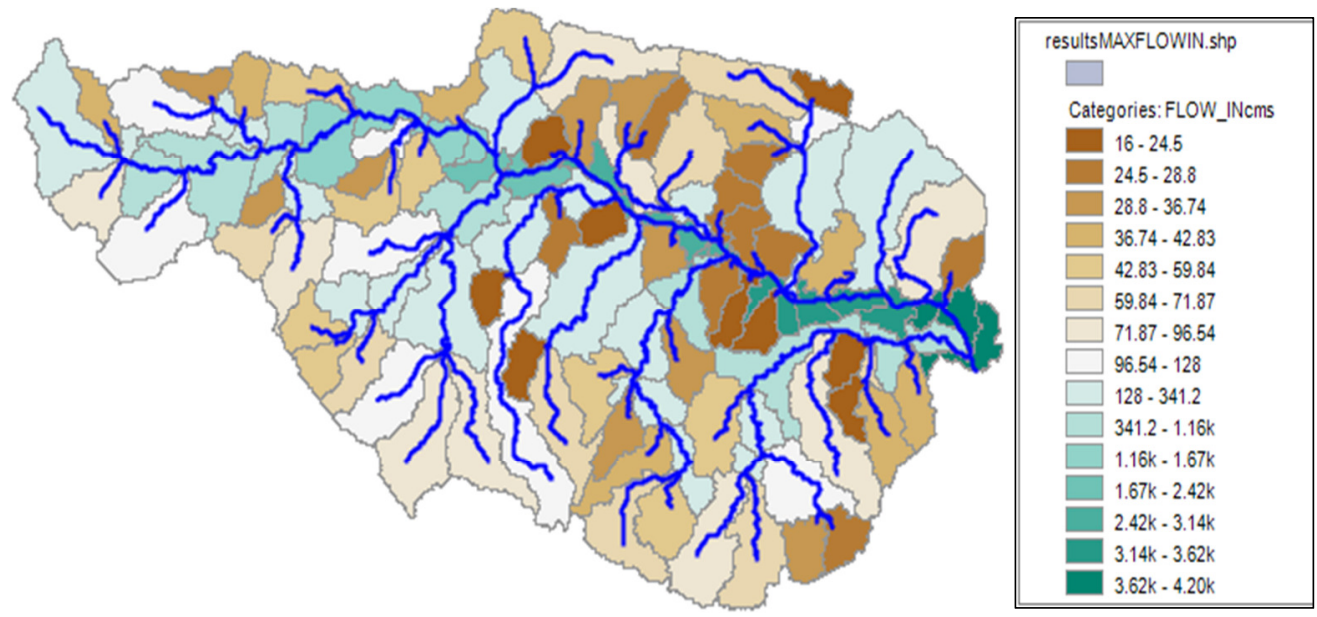

Figure 6: Maximum discharge entering the Sub basins

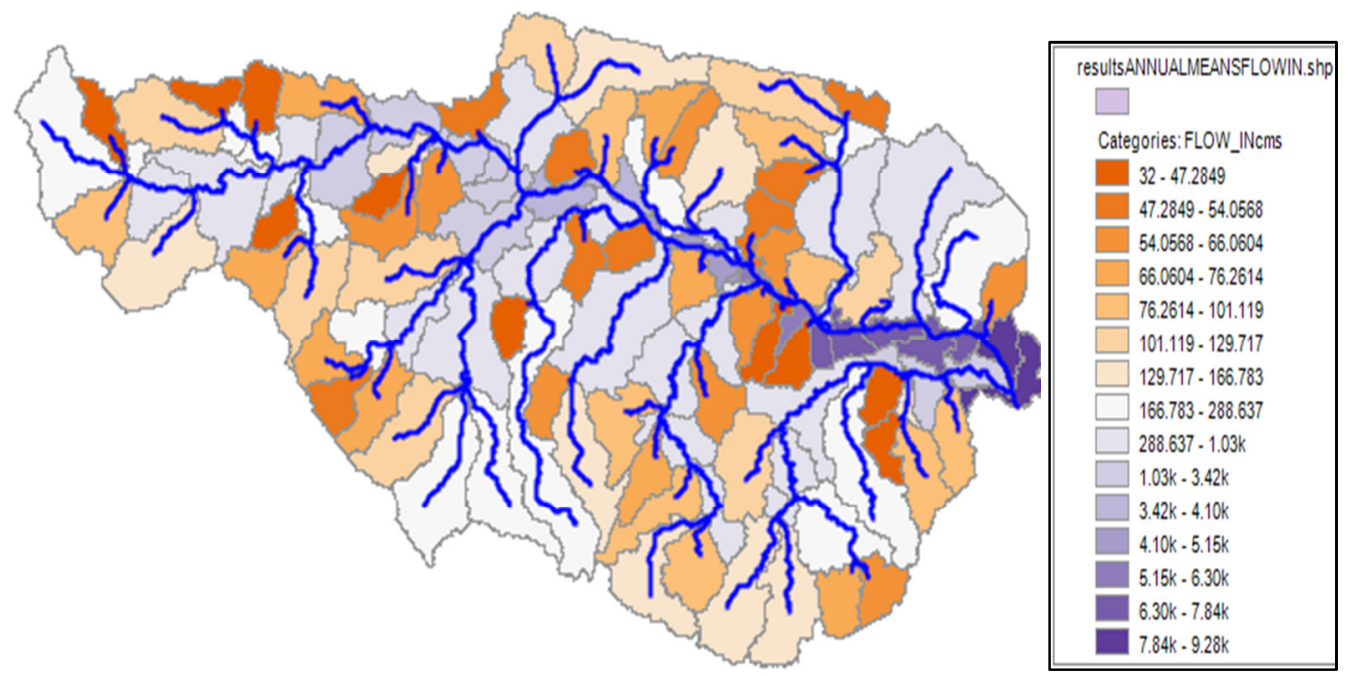

Figure 7: Computed mean annual flow entering the sub basins

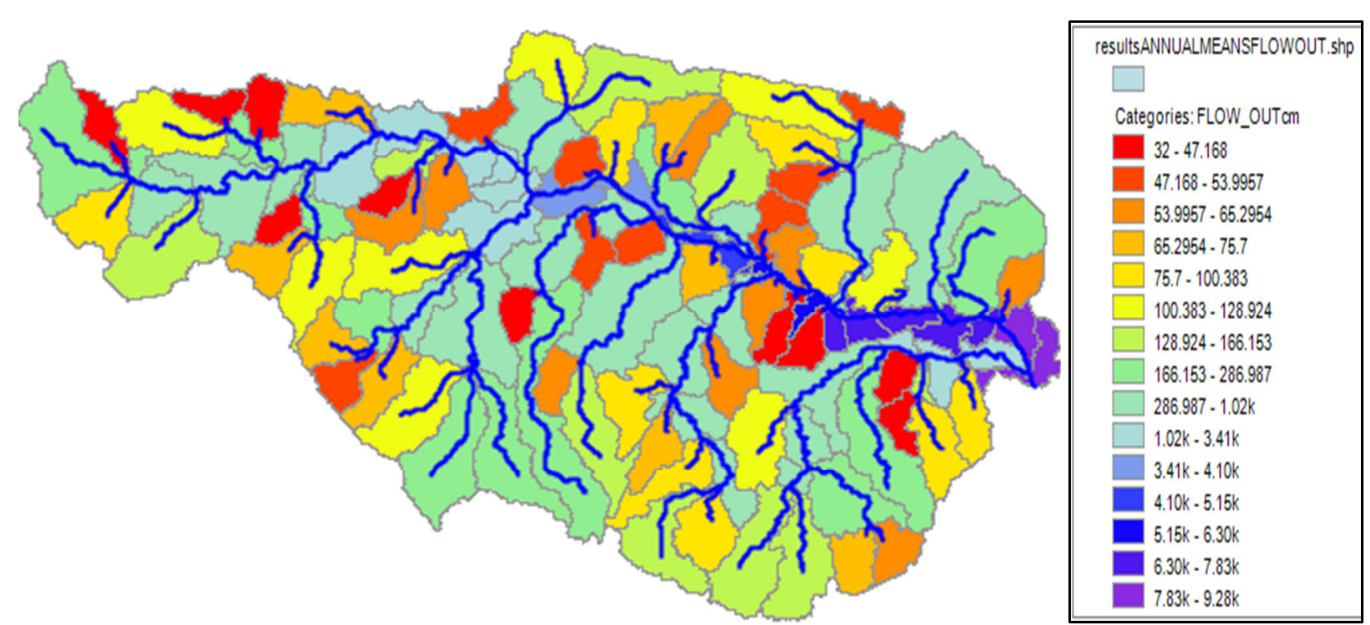

Figure 8: Computed mean annual flow leaving the sub basins 

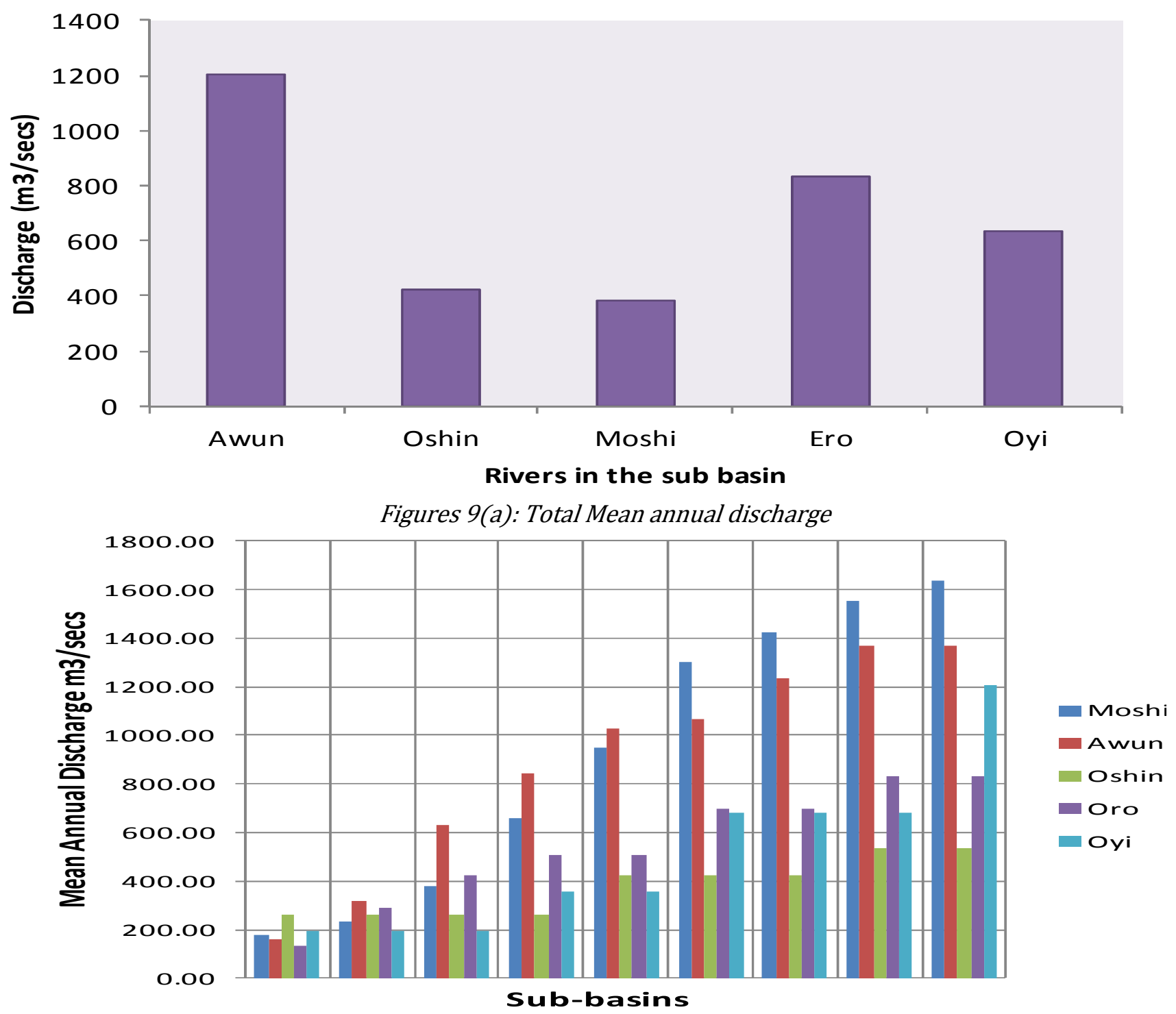

Figures 9(b): Discharge along the Sub Basins of the Rivers

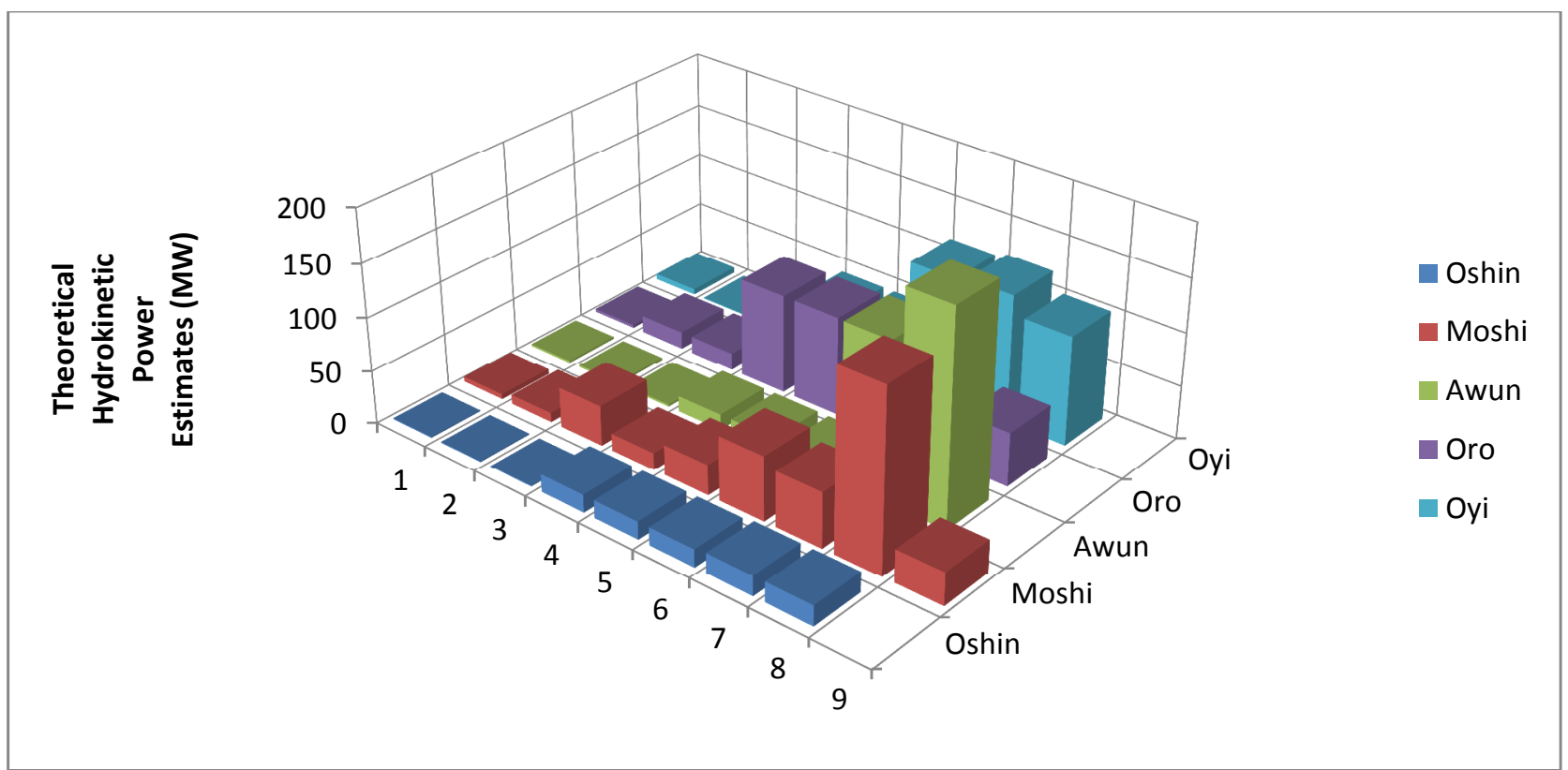

Figure 10: The Theoretical Hydrokinetic Power Resource along the Sub Basins 
Table 1: River sites and their hydraulic parameters (Order $=1)$

\begin{tabular}{|c|c|c|c|c|c|c|}
\hline RIVER & S/BASIN & ORDER & LENGTH (m) & SLOPE & STRAIGHT_L(m) & $\Delta \mathrm{H}(\mathrm{m})$ \\
\hline \multirow{9}{*}{ Moshi } & 8 & 1 & $6,046.10$ & 0.00496186 & $5,469.50$ & 27.14 \\
\hline & 78 & 1 & $14,921.80$ & 0.00274765 & $12,186.40$ & 33.48 \\
\hline & 83 & 1 & $24,579.00$ & 0.00390578 & $19,245.10$ & 75.17 \\
\hline & 90 & 1 & $4,895.10$ & 0.0040857 & $3,850.80$ & 15.73 \\
\hline & 98 & 1 & $6,342.70$ & 0.00346858 & $5,044.00$ & 17.50 \\
\hline & 99 & 1 & $13,416.90$ & 0.00216145 & $11,536.00$ & 24.93 \\
\hline & 106 & 1 & $11,171.20$ & 0.00205886 & $9,274.60$ & 19.10 \\
\hline & 107 & 1 & $18,003.60$ & 0.00411028 & $13,643.50$ & 56.08 \\
\hline & 108 & 1 & $3,153.70$ & 0.00348793 & $2,719.10$ & 9.48 \\
\hline \multirow{4}{*}{ Awun } & 57 & 1 & $5,551.00$ & 0.00216178 & $4,540.50$ & 9.82 \\
\hline & 85 & 1 & $13,789.20$ & 0.00275577 & $11,598.50$ & 31.96 \\
\hline & 86 & 1 & $49,262.40$ & 0.0038772 & $35,781.00$ & 138.73 \\
\hline & 97 & 1 & $118,123.60$ & 0.00220108 & $78,342.10$ & 172.44 \\
\hline \multirow{8}{*}{ Oyi } & 65 & 1 & $15,060.40$ & 0.00285518 & $12,600.80$ & 35.98 \\
\hline & 81 & 1 & 883.10 & 0.00226466 & 754.10 & 1.71 \\
\hline & 88 & 1 & $9,295.10$ & 0.00172134 & $7,777.20$ & 13.39 \\
\hline & 93 & 1 & $26,108.70$ & 0.00153205 & $20,807.80$ & 31.88 \\
\hline & 100 & 1 & 570.90 & 0 & 533.30 & 0.00 \\
\hline & 102 & 1 & $52,382.00$ & 0.00175633 & $34,980.90$ & 61.44 \\
\hline & 104 & 1 & $38,873.60$ & 0.0020065 & $26,479.50$ & 53.13 \\
\hline & 105 & 1 & $22,598.40$ & 0.00256655 & $15,542.70$ & 39.89 \\
\hline \multirow{3}{*}{ Oshin } & 60 & 1 & $2,863.70$ & 0.0010476 & $2,586.60$ & 2.71 \\
\hline & 95 & 1 & $14,322.30$ & 0.00265321 & $10,883.10$ & 28.88 \\
\hline & 103 & 1 & $16,407.30$ & 0.00188941 & $12,522.20$ & 23.66 \\
\hline \multirow{6}{*}{ Oro } & 64 & 1 & $24,869.00$ & 0.00136716 & $17,738.10$ & 24.25 \\
\hline & 84 & 1 & $29,616.40$ & 0.0021272 & $22,076.40$ & 46.96 \\
\hline & 91 & 1 & $30,738.70$ & 0.00679924 & $23,338.10$ & 158.68 \\
\hline & 94 & 1 & $86,849.20$ & 0.00215316 & $51,704.20$ & 111.33 \\
\hline & 96 & 1 & $61,310.20$ & 0.00120698 & $50,426.70$ & 60.86 \\
\hline & 101 & 1 & $16,511.70$ & 0.00308872 & $11,772.10$ & 36.36 \\
\hline
\end{tabular}

Sub-basin 107 in Moshi holds the highest potential for the river followed by 106 . The site at Maje is in subbasin 106. The 93rd sub-basin in Oyi River holds the highest potential. Kpada and Ejiba are also having considerable potential along the Oyi. Sub-basin 103 holds the highest potential on River Oshin. This is downstream Jebba. Oshin site at Bacita road is accessible and has good potentials too. Table 2 presents the rivers and their estimated gross hydrokinetic potential.
Table 2: Average Discharge and Theoretical Hydrokinetic Resource of Rivers

\begin{tabular}{clcc}
\hline S/N & Rivers & $\begin{array}{c}\text { Average Daily } \\
\text { Discharge } \\
\left(\mathrm{m}^{3} / \text { secs }\right)\end{array}$ & $\begin{array}{c}\text { Theoretical } \\
\text { Hydrokinetic Resource } \\
\text { (Gross Power } \\
\text { Estimate, MW) }\end{array}$ \\
\hline 1 & Moshi & 22.78 & 118.0 \\
2 & Awun & 06.68 & 257.5 \\
3 & Oyi & 18.21 & 185.8 \\
4 & Oshin & 03.35 & 20.90 \\
5 & Ero & 07.91 & 174.5 \\
\hline \multicolumn{2}{c}{ TOTAL } & 58.93 & 826 \\
\hline
\end{tabular}




\section{CONCLUSION}

There are naturally occurring potentials of this technology in the Lower Niger River Basin. Based on the preliminary results of the resource assessment, River Moshi has the highest annual average discharge of $8315.78 \mathrm{~m}^{3} / \mathrm{s}$, followed by 0yi with $6644.93 \mathrm{~m}^{3} / \mathrm{s}$, then Ero with $2887.28 \mathrm{~m}^{3} / \mathrm{s}$, then Awun with 2438.01 $\mathrm{m}^{3} / \mathrm{s}$ and lastly Oshin with $1224.27 \mathrm{~m}^{3} / \mathrm{s}$. The estimate of the total annual theoretical hydrokinetic resource for the watershed totals $826.7 \mathrm{MW}$ i.e. 7.247 TWh/yr with Awun having the highest theoretical hydrokinetic potential of $257.5 \mathrm{MW}$ while Oshin has the lowest (20.9 MW).

However, these values may further reduce when other factors surrounding turbine design, type, efficiency and deployment together with local permits, river use, accessibility etc. are considered. Future efforts shall endeavour to estimate the technically recoverable, practicable and accessible hydrokinetic resource across the range of flows at all locations. This is particularly important as rivers and streams exhibit large annual and inter annual variation in flow.

\section{ACKNOWLEDGEMENT}

The authors will like to acknowledge the efforts of Engr. Adeogun A. G., formerly of the Hydrological/ Hydraulics Unit of the National Centre for Hydropower Research and Development, Energy Commission of Nigeria, for his purposeful contributions

\section{REFERENCES}

[1] Khan M. J., Bhuyan G., Iqbal M. T. and Quaicoe J. E., "Hydrokinetic Energy Conversion Systems and Assessment of Horizontal and Vertical Axis Turbines for River and Tidal Applications: A Technology Status Review", Applied Energy, 2009, pp 1823 1835.

[2] Alaska Centre for Energy and Power (ACEP), Hydrokinetic Energy (In-River, Tidal, and Ocean Current), 2011, available at http://energyalaska.wikidot.com/
[3] Natural Resources Canada, Emerging Hydropower Technologies R \& D in Canada: A Strategy for 2007 2011, Technical Report, Natural Resources Canada Hydraulics Energy Group, 2010.

[4] Electric Power Research Institute EPRI, (2012) Assessment and Mapping of the Riverine Hydrokinetic Energy Resource in the Continental United States, Technical Report, EPRI, Palo Alto, CA, pp 1-2

[5] Natural Resources Canada (2008) Assessment of Canada's Hydrokinetic Power PotentialMethodology and Data Review, Technical Report, Natural Resources Canada - Canmet Energy, Ottawa.

[6] Miller G., Joseph F., William L., and Jairo R. (1986) The Allocation of Kinetic Hydro Energy Conversion Systems (KHECS) in USA Drainage Basins: Regional Resource and Potential Power. Technical Report NYU/DAS 86-151, New York University Department of Applied Science. Prepared for the U. S. Department of Energy.

[7] Toniolo H. (2012) Hydrokinetic Assessment of the Kvichak River near Igiugig, Alaska, Using a TwoDimensional Hydrodynamic Model, Energy and Power Engineering, 2012, 4, pp422-431

[8] Ladokun, L. L., Ajao, K. R. and Sule, B. F. (2013) Hydrokinetic Energy Conversion Systems: Prospects and Challenges In Nigerian Hydrological Setting, Nigerian Journal of Technology Vol. 32. No. 3. November 2013, pp. 371-378

[9] Microsoft Encarta (2008) "World Atlas", Microsoft Encarta 2009, Redmond, W.A., Microsoft Corporation.

[10]Michael Pidwirny (2011) Köppen Climate Classification System, The Encyclopedia of the Earth, retrieved from http://www.eoearth.org/ view/article/162263

[11]Sustainable Energy Ireland (SEI) (2006) Tidal \& Current Energy Resources in Ireland retrieved $6^{\text {th }}$ January from (http://streamflow.engr. oregonstate.edu/analysis/flow/) 